
\title{
Strategic Management is Essential for Organisational Growth: A Case Study of Havells
}

\author{
Garima Choubey $^{1}$, Dr. Ashish Mishra ${ }^{2}$ \\ Assistant Professor, Maharashtra Institute of Higher Education \\ Assistant Professor, G. S College of Commerce and Economics, Jabalpur
}

\begin{abstract}
Strategic Management involves the formulation and implementation of the major goals and initiatives taken by a company's top management on behalf of owners, based on consideration of resources and an assessment of the internal and external environment in which the organization competes. Strategic management allows firms to take an objective view of the activities being done by it and do a cost benefit analysis as to whether the firm is profitable. Strategic management allows a firm to orient itself to its market and consumers and ensure that it is actualizing the right strategy.This paper examine How Strategic Management is essential for organisational growth and found the fruitful result after implementing new ideas and strategic policy. The case study of Havells revealed that the genuine application of strategic management enhanced the company's progress.
\end{abstract}

Keywords: Strategic Management, Internal and external environment, Havells.

\section{Introduction}

Strategic management is a continuous process of strategic analysis, strategy creation, implementation and monitoring, used by organizations with the purpose to achieve and maintain a competitive advantage. The term strategic management is used to refer to the entire scope of strategicdecision making activity in an organization. Strategic management as a concept has evolved over time and will continue to evolve. As result there are a variety of meanings and interpretations depending on the author and sources. For example, some scholars and practitioners the term strategic planning connote the total strategic management activities. Moreover, sometimes managers use the terms strategic management, strategic planning, and long-range planning interchangeable. Finally, some of the phrases are used interchangeably with strategic management are strategy and policy formulation, and business policy.

Strategic management consists of the analysis, decisions, and actions an organization undertakes in order to create and sustain competitive advantages. This definition captures two main elements that go to the heart of the field of strategic management. First, the strategic management of an organization entails three ongoing processes: analysis, decisions, and actions. That is, strategic management is concerned with the analysis of strategic goals (vision, mission, and strategic objectives) along with the analysis of the internal and external environment of the organization. Next, leaders must make strategic decisions. These decisions, broadly speaking, address two basic questions: What industries should we compete in? How should we compete in those industries? These questions also often involve an organization's domestic as well as its international operations. And last are the actions that must be taken. Decisions are of little use, of course, unless they are acted on. Firms must take the necessary actions to implement their strategies. This requires leaders to allocate the necessary resources and to design the organization to bring the intended strategies to reality. As we will see in the next section, this is an ongoing, evolving process that requires a great deal of interaction among these three processes.

Second, the essence of strategic management is the study of why some firms outperform others. Thus, managers need to determine how a firm is to compete so that it can obtain advantages that are sustainable over a lengthy period of time. That means focusing on two fundamental questions: How should we compete in order to create competitive advantages in the marketplace? For example, managers need to determine if the firm should position itself as the low-cost producer, or develop products and services that are unique which will enable the firm to charge premium prices-or some combination of both.

\section{Statement of Problems}

At this time many companies are facing different problems like worker unrest, product cost deficiency, product demands in market, new products launching and financial crises. Each and every industry or organization requires strategic planning for business development and growth.

In the current Indian economic climate, whatever the size of your business or organisation, the importance of strategic management is particularly great. To avoid drifting into an iceberg flow, or if already there, to plan a way out and minimise the risk of actually hitting one, you need the visibility good strategic planning gives you. You may suffer the same fate as the Titanic, but you stand a much better chance with it, so consider strategic management as vitally important to good corporate governance too.

\section{Objective of the Study}

1) To ensure the process that resources are obtained and used efficiently in the accomplishment of the organization's objectives.

2) To confirm the efficient acquisition and use of resources, with respect to those activities for which the optimum relationship between outputs and resources can be 


\section{International Journal of Science and Research (IJSR) \\ ISSN (Online): 2319-7064}

Index Copernicus Value (2013): 6.14 | Impact Factor (2015): 6.391

accurately estimated (e.g., financial, accounting, and quality controls).

3) To plan for events beyond the current year, is not synonymous with strategic management (or strategic planning).

\section{Literature Review}

According to David (2009) strategic planning is sometimes confused with strategy formulation, because strategic plan is constructed in this stage. Requirement for sustained competitive advantage. Competitive advantage is what keeps great organizations ahead of their competitors. Rothaermel (2012) pointed out that the company, which has a competitive advantage, performs financially much better than other companies in the industry or better than the industry average. Some companies may achieve it without thorough strategic plan but for the most players out there it is vital to plan strategically, i.e. analyze, create, implement and monitor, and do this continuously.

The organizations don't simply rely on their finances, marketing or operations functional areas to create competitive advantage is that managers of each area often view things only from their own specific angle (Johnson et. al. 2008), which is too narrow view for the whole organization to rely upon. Only the managers (e.g. CEOs or strategic planners) who see the whole picture of the company and its surrounding environments can make the decisions that bring the competitive advantage.

An integrative management fields that combines analysis, formulation, and implementation in the quest for competitive advantage." ${ }^{[2]}$ Strategic management is not about predicting the future, but about preparing for it and knowing what exact steps the company will have to take to implement its strategic plan and achieve a competitive advantage (Blatstein, I.M. (2012). Strategic management is defined as the process by which managers of the firm analyze the internal and external environments for the purpose of formulating strategies and allocating resources to develop a competitive advantage in an industry that allows for the successful achievement of organizational goals (Cox et. al. 2008).

\section{Methodology}

The method of this paper is to review a few important concepts and theories of strategic management as well as strategic planning/ management in Havells India. This paper, therefore, geared towards finding solutions to the problems facing Indian Organisations lukewarm attitude towards work. Havells different annual reports are using as case study as well as data collected from different web sites and International Journals.

\section{Overview on Havells}

Qimat Rai Gupta quit his job teaching in a school in Punjab, and came to Delhi in 1958 with Rs 10,000 in hand. He started an electrical goods trading company in the old part of the city, but the market was too small for his ambitions. He spotted an opportunity in the distressed Havells brand, named after its founder, Haveli Ram Gupta. He bought it for around Rs 7 lakh in 1971, and followed up with a series of acquisitions, joint ventures and entry into new product categories. Today, Havells India Ltd is a Rs 7,248-crore company. The journey hasn't always been smooth, but the roughest patch was easily the 2007 acquisition of German lighting and fixtures maker SLI Lighting, owner of the Sylvania brand.

SLI was then the world's fourth-largest lighting company and 1.5 times bigger than Havells It took Gupta minutes to make up his mind about buying it.

Havells track record of five successful acquisitions, and high growth in its Indian operations.

- In 1983, it bought the loss-making Delhi-based Towers and Transformers Ltd and turned it around in a year.

- Between 1997 and 2001, Havells also bought ECS, Duke Arnics Electronics, Standard Electricals and Crabtree India.

- The last was a 50:50 joint venture between Havells and the UK-based Crabtree,

- Havells later acquired Crabtree's stake in the JV. India revenues had a compound annual growth rate of 50.08 per cent between 2002/03 and 2007/08.

- In March 2007, Havells bought Sylvania. And then the global financial crisis struck.

\section{Economical Crisis Begin}

In March 2007, Havells bought Sylvania. And then the global financial crisis struck. As the meltdown rocked European markets, Sylvania's sales fell, leading to net losses of Euro 16.3 million in 2008/09 and Euro 26.1 million in 2009/10. From Euro 515 million in 2007/08, revenues dropped to Euro 438.4 million in two years. Trusting Sylvania's management to deal with the situation turned out to be a mistake on Havells's part. 


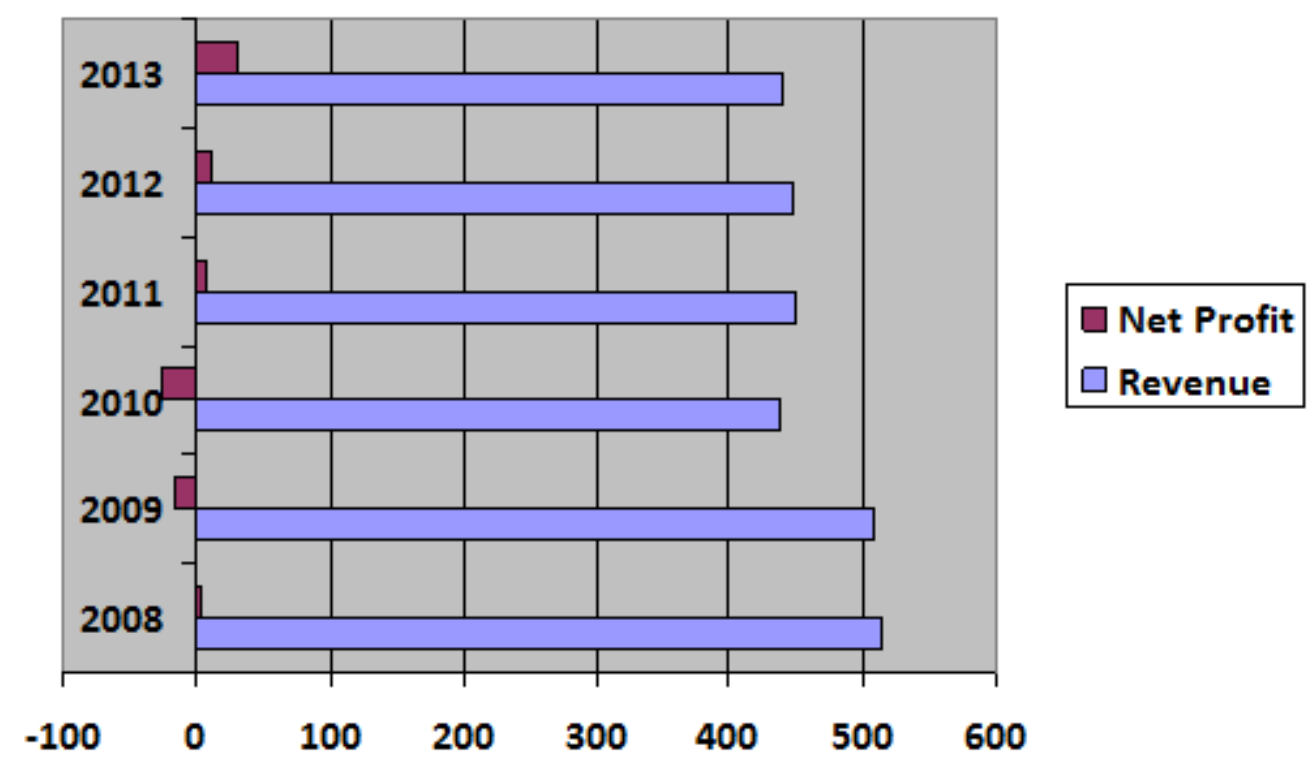

Sylvania's acquisition was funded by debt - a Euro 120million loan based on operating cash flows and a Euro 80million loan taken out by a Havell's subsidiary. Havell's repaid i80 million by raising money from the sale of a stake to Warburg Pincus.

\section{Economical Recostruction Plan of Havells}

Havells's top management drew up an 18-month restructuring plan.

- In the first phase, called Phoenix (January to September 2009), the aim was to improve profitability by cutting manpower costs and closing factories.

- The second phase, called Prakram (September 2009 to June 2010), focused on further reducing the headcount, and increasing the sourcing of products from low-cost locations such as India and China.

- The banks agreed only to a two month deferral of repayment of loans, helping Havells with a Euro 24million cushion for that period. So Havells poured some Euro 12 million into the restructuring plan.

- A factory each in Brazil and Costa Rica were closed. Operations at a UK factory were suspended and shifted to India, where labour accounts for four to five per cent of the total cost (in Europe, it accounts for 22 per cent). Noncritical staff - accounts, IT, factory personnel - in European and Latin American operations was also laid off. Some back-office jobs were shifted to India. The total headcount of 3,800 (at the start of 2009) was reduced by 41 per cent to 2,233.

- Besides reducing the headcount, several areas were targeted including logistics, inventory management, and product pricing. Havells worked closely with logistics companies and shut down some warehouses, reducing logistics costs from 14 to six per cent of total cost.

- To reduce the working capital requirement, the amount of inventory at the company level was cut from Euro 7075 million to Euro 40 million without affecting the ability to serve customers on time. Since 2007, outsourcing from India and China has jumped from 38 to 60 per cent.
- Sylvania's products were priced 15 per cent lower than those of rivals Philips, Osram and GE. This was of little help to Sylvania, which makes high-end products, and also diluted the brand. " Havells raised prices in Europe and Latin America by five to eight per cent,"

\section{Toward Fruitful Results}

The results soon began to show. In 2010/11, Sylvania made a net profit of Euro 7 million on revenues of Euro 449.4 million. Since then, profits have grown steadily: Euro 10.2 million in 2011/12 and Euro 30.5 million in 2012/13, although revenues stayed somewhat flat (Euro 449.4 million in 2011/12 and Euro 439.9 million in 2012/13). The company has seven factories (it closed one more in the UK in 2009) and a workforce of 2,200 in 50 countries.

The persistent slowdown in Europe remains a concern for Sylvania. Europe contributes 55 per cent to its top line, down from 70 per cent some years ago.

\section{Conclusion}

A sequential process involving strategy, plans, identification of possible targets, negotiation, evaluation, streamlining of the final deal, value creation, culture fit and growth aids a successful acquisition. Valuation techniques which take into consideration synergies accruing to buyer and seller, digressions, deal structure, performance measures, cost, market, management of talent, accountability and so on are other critical issues in evaluating a marriage between two companies. The final critical point is that the agreed value of an M\&A deal needs to be justified by sales turnover, profitability, cash flows and so on, which the acquisition is supposed to yield. Without establishing the worth of these variables, it is impossible to identify the value of the company being taken over. This said, the Euro 3 million excess paid for Sylvania is marginal, considering the value of the deal was Euro 200 million.

Even after doing all this, the decision to execute a crossborder takeover of a company that is 1.5 times bigger than the acquirer, with worldwide sales and production, is not 


\section{International Journal of Science and Research (IJSR) \\ ISSN (Online): 2319-7064}

Index Copernicus Value (2013): 6.14 | Impact Factor (2015): 6.391

easy. It appears that much of Havells's post-merger problems was due to environmental factors - an economic downturn and Sylvania's operational inefficiencies. In fact, this can be seen as a blessing in disguise - many tough decisions such as restructuring and layoffs find greater acceptability among staff when the environment is bad. Havells's decisions to close three factories, increase sourcing from cheaper markets, move their focus to Latin America and Asia, and reduce dependence on European markets, competitive pricing, and so on were all steps in the right direction. Likewise, fixed cost reduction was an important first step in the turnaround. Havells also involved the local management in decision-making and let go of their ineffective CEO. True, they could have done this earlier, but it is important to time and sequence one's moves so they don't backfire. It takes time for the results of broad-based changes to show, and HaveIls has recorded increasing profits year-on-year since 2011.

\section{References}

[1] Blatstein, I.M. (2012). Strategic Planning: Predicting or Shaping the Future? Organization Development Journal, Vol. 30 Issues 2, pp. 32

[2] Business Gateway (2012). Strategic planning: the basics. Available at: http://www.bgateway.com/growimprove/growing-a-business/strategic-planning-thebasics/\#page-1576

[3] Cox, M. Z., Daspit, J., McLaughlin, E. and Jones III, R.J. (2012). Strat.Mgmt.: Is It an Academic Discipline? Journal of Business Strategies, Vol. 29 Issue 1, pp. 27-28

[4] David, F.R. (2009). Strat. Mgmt.: Concepts and Cases. 12th ed. FT Prentice Hall, p. 36-37, 40, 48

[5] Johnson, G, Scholes, K. Whittington, R. (2008). Exploring Corporate Strategy. 8th ed. FT Prentice Hall, p. $11-12$

[6] Rothaermel, F. T. (2012). Strat. Mgmt.: Concepts and Cases. McGraw-Hill/Irwin, p. 5

[7] Wikipedia (2013). Strategic Management. Available at: http://en.wikipedia.org/wiki/Strategic_management 